\title{
Interest Student Learning: Empirical Study of The Use of Gadget and Learning Environment
}

\author{
Lue Sudiyono, IKIP PGRI,Wates, Yogyakarta, Indonesia, luesudiyono56@gmail.com. \\ Anita Dewi Astuti, IKIP PGRI,Wates, Yogyakarta, Indonesia
}

\begin{abstract}
This study uses a quantitative approach which aims to determine the effect of gadget use and the environment on students' learning interest. The sampling technique used a proportional random sampling technique by lottery in order to obtain a sample of 47 students. Data collection using a questionnaire. The analysis used multiple regression techniques with the help of SPSS version 20 for windows. The results of the data analysis concluded that there was no influence on the use of gadgets and the environment of grade IX students at 9 Purworejo Junior High School for the 2019/2020 Academic Year. The research findings showed that the use of gadgets and the environment did not have a significant impact on interest in learning ( $p>0.05)$. This is indicated by a small impact of $11.30 \%$ use of gadgets and $23.20 \%$ of the influence of the environment on interest in learning, thus this research recommends that schools provide education about the importance of interest in learning to achieve expected achievements and provide learning support facilities such as better facilities and infrastructure so that the environment learning becomes more comfortable in the era of technological development. In addition, the importance of cooperation between parents, teachers, and schools so that the use of gadgets is used by students for learning purposes.
\end{abstract}

Keywords: Educational Technology, Use Of Gadgets, Learning Environment, Interest In Learning. Received: 03.11.2020 Accepted: 14.12.2020 Published: 10.01.2021

\section{INTRODUCTION}

The development of information technology which is increasingly rapid in the current era of globalization cannot be avoided its impact on the world of education. Global demands require the world of education to always and constantly adapt technological developments to efforts to improve the quality of education, especially adjusting the use of information and communication technology for education, especially in the learning process (Hernandez et al., 2019; Pedro et al., 2019; Coccia, 2019; Xie et al., 2019Teräs et al., 2020). Changes in these demands make the world of education require innovation and creativity in the learning process because many people propose in education, especially learning, but very few people talk about problem-solving solutions about the learning and teaching process that are in accordance with global demands.

The development of information and communication technology has had an impact on the world of education in Indonesia, especially in the learning process. According to Gunawan (2009), with the growing use of information and communication technology there are five shifts in the learning process, namely: 1) from training to performance, 2) from classrooms to anywhere and anytime, 3) from paper to "on line "or channel, 4) from physical facilities to network facilities, 5) from cycle time to real time. Apart from teachers, technology also has its own role for students and has an impact on students' interest in learning.

According to Djaali (2015: 121) "Interest is a feeling of preference and interest in something or activity, without being asked". This definition refers to the sense of interest that a person has without encouragement, as well as students of the importance of awareness to have an interest in learning activities that are taking place, because interest will encourage students to show participatory attitudes, and full concentration in following learning as it takes place. Furthermore, learning is a change in personality that states itself as a new pattern of reactions in the form of skills, attitudes, habits and intelligence (Ngalim, 2013; Mazza et al., 2019; Juhasz et al., 2019; Nunaki et al. , 2019; Gorgoz, S., \& Tican, 2020; Vosniadou et al., 2020). So that learning is essentially a complex internal process, that internal includes the affective domain which has support from the psychomotor function. learning can certainly involve a function of the realm of reason.Learning will occur changes in good behavior where these changes occur through the learning environment and interest in learning (Jalal et al., 2019; Vansteenkiste et al., 2019; Nurtanto et al., 2020) There are several factors that can affect interest in learning in general, namely due to internal and external factors of students, and in particular, the use of gadgets and the learning environment. 
According to Rohman (2017), a gadget or smartphone is a mini mechanical device or tool or an interesting tool because it is relatively new so that it will provide many new pleasures for its users even though it may not be practical in its use. Students are allowed the school to bring gadgets in the school environment to make learning more focused on their respective gadgets, even though they have been admonished when class lessons take place, sometimes students also argue. In addition, the interest in reading books in the library during recess is also very rare that students want to read, but they prioritize gadgets. The term book as a window to the world seems to have disappeared in the world of education, replaced by the use of gadgets

Then Saroni (Jamal, 2011), suggests "the learning environment is everything related to where the learning process is carried out". In a different learning environment, the way students learn from one another is also different, some are active in learning and some are not active, there are also some students who want to pay attention to the teacher while learning is taking place and some are not paying attention. So that the learning environment is said to be able to determine the success or failure of students in learning. Conversely, if students lack interest in learning, it will cause students to be hampered in learning and cause a lack of effort or laziness.

Higher education has an important role in the life of a nation because education is very important in national development. The education process cannot be separated as an effort to develop HR (Human Resources). Education in schools has the aim of shaping students into qualified human beings so that they become the driving force for progress with integrity. A student will get maximum learning outcomes if the teacher provides positive reinforcement or motivation to students to really have an interest in learning so that learning achievement will be even higher. However, recently, with the gadgets that are being loved by almost all teenagers, especially students, it has an impact on the learning process, especially their interest in learning.

Based on observations at the 9 Purworejo Junior High School when the learning took place students paid attention to the explanation from the teacher concerned, but after a few minutes the students were even interested in playing gadgets so that students no longer paid attention to the teacher's explanation. During the discussion, students chat with a friend next to their seat outside the class discussion theme, when the teacher asks the results of the discussion, students ask for an extension of time to the teacher because they haven't finished answering the assignment given by the teacher. In the classroom, students are always looking for opportunities to use gadgets so that learning is less conducive. In this phenomenon, it shows that student interest in learning becomes low due to the impact of using gadgets. Not only experienced by students at SMP Negeri 9 Purworejo, but also experienced by many other schools.

\section{LITERATURE REVIEW}

Today's modern technological advances are increasingly rapid and advanced so that it has made many changes to human life in various fields, especially in the field of education. Gadget technology makes it easier for students to be able to access exam grids on certain subjects, check the list of test scores, register for schools, even to continue their education at leading campuses. It has a very large impact on the value of life, especially when someone spends time using gadgets. However, excessive use of gadgets has a negative impact on health both physically and psychologically.

According to Rohman (2017), that what is meant by gadget is "a mini mechanical device or tool or an interesting tool because it is relatively new so that it will provide many new pleasures for its users even though it may not be practical in its use".

Furthermore, according to Chusna (2017) "gadget is a term in English which defines a small device with various special functions that are useful for something new". This definition refers to the positive benefits of using gadgets as a means or practical means of communication or what is known as a mobile phone.

The impact of the positive impact of using gadgets, namely: Derry Iswidharmanjaya (2014: 11) suggests that the use of gadgets is positive if they are used efficiently, namely building to improve in the academic aspect, increasing language skills, reducing the level of boredom in learning, in the sense that it can reduce tension by playing games, listening to favorite songs and chatting with classmates through chat applications, creating mathematical skills, where a student is stimulated by mathematical abilities such as the use of graphic design software, and stimulates to keep up with the latest technological developments, that is, a gadget user will keep up with technological developments that are increasingly everday.

Technological progress has a negative impact, namely forming students to be lazy to carry out their activities, including when studying, increasing diseases, namely eating irregularly, damaging eyes, and causing social separation where students become individual and lack interaction with others. The negative impact of using gadgets, according to Suwarsi (2016: 25) states that there are several negative impacts for 
students, namely reading interest is low because they are more interested in learning with motion and pictorial media, learning and playing activities make them have an individualistic attitude or prefer to be alone. Many students play gadgets on their days off instead of playing with their friends. In this case, the attraction to other activities becomes lazy. Ineffective use of gadgets creates a high level of dependency and reduces students' memory and concentration during learning hours. Children begin to become addicted to gadgets, so they forget to socialize with the surrounding environment which will have an impact on children's psychology, especially the emergence of a low self-confidence crisis. In addition, learning to socialize with fellow friends is very important to understand a rule that must be applied to oneself or even the custom of being a good friend. However, the fact is that students prefer to spend their time playing gadgets. So it can be concluded that the use of gadget technology currently has a negative and positive impact depending on its use. According to Crow and Crow, quoted from Ristiana (2001:14), there are three factors that influence the emergence of interest, namely:

1) Internal driving factors, which are factors that come from within, such as hopes and desires that encourage concentration of attention and active mental involvement.

2) Social motive factors, are factors that generate interest in things that have to do with meeting social needs for themselves.

3) Emotional factor, is the intensity of a person in paying attention to an activity or object.

In developing a student learning environment in order to generate interest in learning and to produce superior future generations is determined by several factors, both the bad and the learning outcomes of students are influenced by several factors, namely the learning environment and interest in learning. Nowadays, increasingly sophisticated technology cannot be separated from the use of a gadget because it is a primary need. Gadgets have a positive impact where they can facilitate communication and provide information in everyday life so that they become more flexible in their use. However, excessive use can interfere with health and become dependent on gadgets that will have a bad or negative impact and affect other activities. Education in students will develop if they can use it appropriately and efficiently.

The learning environment is the formation of students' personality traits (Odrekhivskyy et al., 2019; Kurniawati, E. K., \& Sunarso, 2019; Babieva et al., 2019; Dewantara et al., 2020; Goloshumova et al., 2020). Students who are diligent in learning will be created if the environment around them provides support and direction. So that students can use their time to learn through their learning environment. Able to take advantage of the time not to spend time with the gadgets they have. The learning environment will later affect students' interest in learning by seeing the results of their learning.

Learning interest acts as a student's strength to want to learn without having to be forced, but interest also arises because of encouragement or stimulants from outside. The role of interest in the development of student learning. Students who have an interest in certain fields will try harder to learn and practice. Seeing the current phenomenon with gadgets will affect the learning environment and interest in learning. Although there is a positive impact on the use of gadgets, it also has a negative impact where students currently use them inefficiently during class hours so that time is wasted, disturbing eye health.

The hypotheses in this study are:

$\mathrm{H} 1$ : There is an influence between the use of gadgets and the learning environment on the learning interest of class IX students of SMP Negeri 9 Purworejo.

\section{RESEARCH METHODS}

The type of data in this study is primary data. This research was conducted at 9 Purworejo Junior High School, with the subject taking in class IX of the 2019/2020 school year. This research was conducted from December 2019 to January 2020.

The variables used in this study consist of two independent variables and one dependent variable. The independent variable is the use of gadgets (X1) and the learning environment (X2), while the dependent variable is interest in learning $(Y)$. The sampling technique used in this study was a proportional random sampling technique by lottery because the researchers paid attention to the proportions in each class. The number of samples taken in each class can be seen in table 1.

Table 1. Sample distribution for class IX SMP Negeri 9 Purworejo 2019/2020 year.

\begin{tabular}{|l|l|l|}
\hline \multicolumn{1}{|c|}{ Class } & amount & Sample 25 \% \\
\hline IX A & 32 & 8 \\
\hline IX B & 32 & 8 \\
\hline IX C & 32 & 8 \\
\hline
\end{tabular}




\begin{tabular}{|l|l|l|}
\hline IX D & 32 & 8 \\
\hline IX E & 32 & 8 \\
\hline IX F & 30 & 7 \\
\hline TOTAL & 190 & 47 \\
\hline
\end{tabular}

Table 1, the researcher will use a sample of $25 \%$ of the total students of class IX, namely, of the 190 students the sample taken is 47 students. With the conditions of being a sample, namely students who have gadgets. The data was collected by using the interview method and the questionnaire method in the form of a series of written questions addressed to the respondent and filled in by the students (respondents).

Data analysis technique is defined as a method or way to process data into information so that the characteristics of the data become easy to understand and also useful for finding solutions to problems from a study. The data analysis technique used in this research is multiple linear regression analysis techniques. This analysis is used to determine the direction of the relationship between the independent variable $(\mathrm{X})$ and the dependent variable $(\mathrm{Y})$ whether it is positive or negative.

\section{RESULTS AND DISCUSSION}

Research hypothesis testing can be done by simultaneously testing and partially testing. Hypothesis testing is shown in Table 2 and Table 3.

Table 2. Simultaneous Test

\begin{tabular}{|ll|l|l|l|l|r|}
\hline Model & & Sum of Squares & df & Mean Square & F & Sig. \\
\hline 1 & Regression & 89.288 & 2 & 44.644 & 1.278 & $.289 \mathrm{~b}$ \\
& Residual & 1536.584 & 44 & 34.922 & & \\
& Total & 1625.872 & 46 & & & \\
\hline
\end{tabular}

Simultaneous test with the F test obtained F Statistics of 1.278 and a significance value of $0.289>0.05$, so it can be concluded that the estimated linear regression model is not suitable to be used to explain the effect of gadged and environmental use on learning interest simultaneously. Furthermore, the relationship will be tested partially in Table 3 .

Table 3. Partial Test

\begin{tabular}{|c|c|c|c|c|c|c|}
\hline \multirow{2}{*}{\multicolumn{2}{|c|}{ Model }} & \multicolumn{2}{|c|}{$\begin{array}{l}\text { Unstandardized } \\
\text { Coefficients }\end{array}$} & $\begin{array}{c}\text { Standardized } \\
\text { Coefficients }\end{array}$ & \multirow[t]{2}{*}{$\mathrm{t}$} & \multirow[t]{2}{*}{ Sig. } \\
\hline & & B & Std. Error & Beta & & \\
\hline 1 & $\begin{array}{l}\text { (Constant) } \\
\text { learning environment } \\
\text { (X2) } \\
\text { Gadget_use (X1) }\end{array}$ & $\begin{array}{l}30.237 \\
.113 \\
.232\end{array}$ & $\begin{array}{l}9.855 \\
192 \\
177\end{array}$ & .089 & $\begin{array}{l}3.068 \\
.589 \\
1.312\end{array}$ & $\begin{array}{l}.004 \\
.559 \\
196\end{array}$ \\
\hline
\end{tabular}

a. Dependent Variable: interest to learn (Y)

Table 2 shows that the gadget usage variable has a tcount of 0.589 with a significance of $0.559>$ 0.05. so that partially the variable use of gadgets has no effect on interest in learning. Partial test of the learning environment obtained tcount (1.312) <ttable (1.680) and a significance value (0.196)> (0.05). So it can be concluded that Ho is accepted and Ha is rejected. So that partially the learning environment does not have a positive effect on interest in learning. The contribution of the use of gadgets and the learning environment to interest in learning was 5.5\%, while the rest was influenced by other variables not included in this study.

Table 4. Coefficient of determination

\begin{tabular}{|c|c|c|c|c|c|c|c|c|c|}
\hline \multirow[b]{2}{*}{ Model } & \multirow[b]{2}{*}{$R$} & \multirow[b]{2}{*}{$\begin{array}{l}\mathrm{R} \\
\text { Square }\end{array}$} & \multirow{2}{*}{\begin{tabular}{|l|} 
Adjusted \\
$\mathrm{R}$ \\
Square
\end{tabular}} & \multirow{2}{*}{$\begin{array}{l}\text { Std. Error of } \\
\text { the } \\
\text { Estimate }\end{array}$} & \multicolumn{5}{|c|}{ Change Statistics } \\
\hline & & & & & $\begin{array}{l}\mathrm{R} \text { Square } \\
\text { Change }\end{array}$ & F Change & df1 & $\mathrm{df} 2$ & $\begin{array}{l}\text { Sig. } \\
\text { Change }\end{array}$ \\
\hline
\end{tabular}




\begin{tabular}{|l|l|l|l|l|l|l|l|l|r|}
\hline 1 & .234 & & & & & & & \\
& $\mathrm{a}^{2}$ & .055 & .012 & 5.910 & .055 & 1.278 & 2 & 44 & .289 \\
\hline
\end{tabular}

Based on the results of data processing, the regression analysis equation model is obtained as follows:

$Y_{2}=30.237+0,113 X_{1}+0,232 X_{2}+\varepsilon t$

The findings show that the use of gadgets has no impact on interest in learning with an impact of $11.30 \%$. The finding in the field is that the use of gadgets based on the results of student questionnaires is not more than two hours / day, so that in this case it does not make students addicted to gadgets. This is supported by the Balitbang theory (2017: 456) that the category of smartphone or gadget dependency is when: 1) sleeping late due to playing gadgets, 2) using it for more than two hours, 3) being obsessed with finding new things in gadgets, 4 ) neglect work for the sake of playing gadgets for a long time, 5) they can't live without gadgets.

Apart from this, the environmental impact on interest in learning was $23.20 \%$, which did not have a significant impact on interest in learning. This is indicated by a supportive family environment such as meeting school needs, keeping the home atmosphere comfortable and calm while studying. Supporting school factors such as teachers making learning media, as well as community environmental factors, the majority of which have a high educational background. Learning interest also has no effect, this is supported by the theory according to Crow \& Crow (Prima Dwi Utama, 2009: 15) that the aspects of interest consist of interest, attention, awareness, and concentration.

The use of gadgets can be interpreted as the strength in a person to use smartphone technology as a useful medium to support daily activities. The learning environment is everything that is outside the student, both socially or physically (non-social) which has an effect either directly or indirectly on the student learning process. The basic conditions of the learning environment do not prevent students from learning.

Learning interest is an aspect of psychology that shows itself in several symptoms such as desire, a feeling of pleasure in carrying out the change process with various activities to seek knowledge and experience in other words, this interest is student interest in learning which can be shown through enthusiasm. The results of the research above are in line with the research conducted by The results of the research above are in line with the research conducted by Adeng Hudaya (2018) that the use of gadgets does not have a linear effect on students' interest in learning. The interest of students determines student learning activities without interference with learning activities such as the use of gadgets, so that the factors that influence the research above are students tend to pay more attention to something in their activities as a focus for achieving goals.

Based on the results of this study that there is no significant influence on the use of gadgets and the learning environment on student interest in learning, the factors that influence this include: students are good at using gadgets as needed to obtain information in improving academic aspects, good at taking advantage of opportunities in the middle of busy life, a learning environment support as a learning resource, have an interest in learning so that learning awareness grows without coercion. Referring to the theory of Clark C. Hull, 2009: 96, the function of interest in learning uses the principles of behavior based on motive motivation as a need that exists in students who are learning who tend to have clear directions about the goals to be achieved.

\section{CONCLUSION}

Based on the results of this study, it was found that the use of gadgets and the learning environment did not make a significant contribution to increasing the interest in learning of class IX students of SMP Negeri 9 Purworejo. Based on this, it is hoped that cooperation between parents, counseling guidance teachers will provide direction or guidance to grade IX students to continue to increase their interest in learning to use gadgets for learning purposes and not for playing games in the era of technological development.

\section{REFERENCES}

Babieva, N. S., Grinenko, A. V., Shulga, T. I., Tkhugo, M. M., Zotova, L. E., Shukshina, L. V., \& Ishkov, A. D. (2019). A Psychological Resource of Personality as an Integral Eco-Psychological Characteristic (The Interrelationship of Personal Development and Quality of Human Life). Ekoloji Dergisi, (107).

Balitbang. (2017). Panduan Pelaksanaan Penelitian. Jakarta.

Chusna, P. A. (2017). Pengaruh media gadget pada perkembangan karakter anak. Dinamika Penelitian: Media Komunikasi Penelitian Sosial Keagamaan, 17(2), 315-330. 
Coccia, M. (2019). Why do nations produce science advances and new technology?. Technology in society, 59, 101124.

Dewantara, J. A., Efriani, E., Sulistyarini, S., \& Prasetiyo, W. H. (2020). Optimization of Character Education Through Community Participation Around The School Environment (Case Study in Lab School Junior High School Bandung). JED (Journal of Etika Demokrasi), 5(1), 53-66.

Djaali. (2015). Psikologi Pendidikan. Jakarta: Bumi Aksara.

Goloshumova, G. S., Ershova, O. V., Salakhova, V. B., Kidinov, A. V., Nalichaeva, S. A., \& Yanysheva, V. A. (2019). Information and educational environment of higher school as a factor of the formation of coping strategies in the structure of students' personality (ecological and psychological aspect). EurAsian Journal of BioSciences, 13(2), 1867-1874.

Gorgoz, S., \& Tican, C. (2020). Investigation of Middle School Students' Self-Regulation Skills and Vocabulary Learning Strategies in Foreign Language. International Journal of Educational Methodology, 6(1), 25-42.

Hernandez-de-Menendez, M., \& Morales-Menendez, R. (2019). Technological innovations and practices in engineering education: a review. International Journal on Interactive Design and Manufacturing (IJIDeM), 13(2), 713-728.

Hull, C. L. Principle of Behavior. New York : Appleton Century Grofts, 1948.

Iswidharmanjaya, Derry. 2014. Bila Si Kecil Bermain Gadge: Panduan bagi Orang Tua untuk Memahami Faktor-faktor Penyembab Anak Kecanduan Gadget. Google Books

Jalal, A., \& Mahmood, M. (2019). Students' behavior mining in e-learning environment using cognitive processes with information technologies. Education and Information Technologies, 24(5), 27972821.

Juhasz, D., Nemeth, D., \& Janacsek, K. (2019). Is there more room to improve? The lifespan trajectory of procedural learning and its relationship to the between-and within-group differences in average response times. PloS one, 14(7), e0215116.

Kurniawati, E. K., \& Sunarso, S. (2019). Forming Students' Character through School Culture in Senior High School Taruna Nusantara Magelang. Jurnal Ilmiah Peuradeun, 7(1), 141-162.

Mazza, C., Monaro, M., Orrù, G., Burla, F., Colasanti, M., Ferracuti, S., \& Roma, P. (2019). Introducing machine learning to detect personality faking-good in a male sample: a new model based on Minnesota multiphasic personality inventory-2 restructured form scales and reaction times. Frontiers in psychiatry, 10.

Nugroho, S, Julianto, A, dkk. (2007). IPS untuk Kelas VI SD/ MI. Jakarta: Pusat Perbukuan, Depdiknas.

Nunaki, J., Damopolli, I., Kandowangko, N., \& Nusantri, E. (2019). The effectiveness of inquiry-based learning to train the students' metacognitive skills based on gender differences.

Nurtanto, M., Fawaid, M., \& Sofyan, H. (2020, July). Problem Based Learning (PBL) in Industry 4.0: Improving Learning Quality through Character-Based Literacy Learning and Life Career Skill (LLLCS). In Journal of Physics: Conference Series (Vol. 1573, No. 1, p. 012006). IOP Publishing.

Odrekhivskyy, M., Pasichnyk, V., Rzheuskyi, A., Andrunyk, V., Nazaruk, M., Kunanets, O., \& Tabachyshyn, D. (2019). Problems of the Intelligent Virtual Learning Environment Development. In MoMLeT (pp. 359-369).

Pedro, F., Subosa, M., Rivas, A., \& Valverde, P. (2019). Artificial intelligence in education: Challenges and opportunities for sustainable development.

Prima Dwi Utama. (2009). Hubungan antara Keharmonisan keluarga dengan Minat Belajar pada SiswaSiswi SMU PIRI I Yogyakarta. Skripsi. Yogyakarta: Fakultas Psikologi Universitas Ahmad Dahlan.

Purwanto, N. (2013). Evaluasi Hasil Belajar. Bandung: Remaja Rosdakarya

Ristiana. (2001). Meningkatkan Minat Belajar. Skripsi: UNY

Rohman. (2017). Panduan Penulisan Karya Ilmiah. Jakarta: Pustaka Pelajar

Saroni. (2011). Interaksi dan Motivasi Belajar. Yogyakarta: Ar-Ruzz Media.

Suwarsi, S. (2016). Analisis faktor penyebab perilaku seksual pranikah pada remaja di desa Wedomartani Sleman Yogyakarta. Jurnal Ners dan Kebidanan Indonesia, 4(1), 39-43.

Teräs, M., Suoranta, J., Teräs, H., \& Curcher, M. (2020). Post-Covid-19 education and education technology 'solutionism': A seller's market. Postdigital Science and Education, 1-16.

Vansteenkiste, M., Aelterman, N., Haerens, L., \& Soenens, B. (2019). Seeking stability in stormy educational times: A need-based perspective on (de) motivating teaching grounded in self-determination theory. In Motivation in Education at a Time of Global Change. Emerald Publishing Limited.

Vosniadou, S., Lawson, M. J., Wyra, M., Van Deur, P., Jeffries, D., \& Ngurah, D. I. G. (2020). Pre-service teachers' beliefs about learning and teaching and about the self-regulation of learning: A conceptual change perspective. International Journal of Educational Research, 99, 101495. 
Xie, H., Chu, H. C., Hwang, G. J., \& Wang, C. C. (2019). Trends and development in technology-enhanced adaptive/personalized learning: A systematic review of journal publications from 2007 to 2017. Computers \& Education, 140, 103599. 